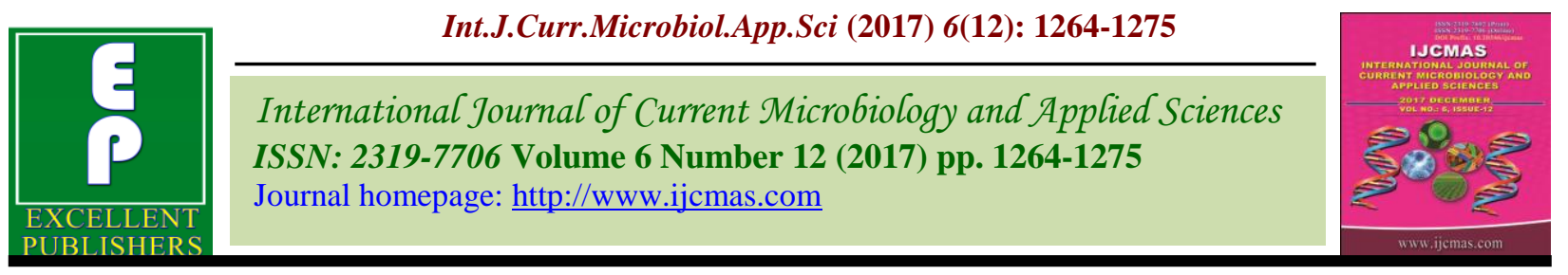

Original Research Article

https://doi.org/10.20546/ijcmas.2017.612.143

\title{
Effect of Paclobutrazol on Vegetative Response Production of Mango (Mangifera indica L., var. Himsagar)
}

\author{
P. Pal*, S. Mondal and S. Kundu \\ Department of Plant Physiology, Bidhan Chandra Krishi Viswavidyalaya, \\ Mohanpur-741252, Nadia, West Bengal, India \\ *Corresponding author
}

\section{A B S T R A C T}

Keywords

Mango, Himsagar,

Paclobutrazol,

September

treatment.

Article Info

Accepted:

10 October 2017

Available Online:

10 December 2017
The experiment was conducted at the Central Research Farm of Krishi Vigyan Kendra, Bidhan Chandra Krishi Viswavidyalaya, Gayeshpur, Nadia, West Bengal, India during the years 2015-2016 in randomized block design. Paclobutrazol @ 2.5 g.a.i/tree was applied in soil drench of 15 years old un-pruned grafted mango plant cv. Himsagar on first day of each month from July to February along with the untreated control were considered as nine treatments, that were triplicated considering each plant as replication. To increase the flowering and fruiting (reproductive growth) checking of vegetative growth is very important. Effect of different paclobutrazol treatment on checking the vegetative growth of mango was observed and among the treatments September treatment were found to be significant influence on checking different vegetative organ growth of the plant.

\section{Introduction}

Mango (Mangifera indica L.) is the most popular fruit in West Bengal. India obtains first place in the field of the production of the mango but the production per hectare is so low that is keeps India much lower position in respect of other countries of the world. In spite of fertile soil and favourable environmental condition, the cause of lower production is too much vegetative growth of the same variety. A popular type of mango var. is 'Himsagar' in West Bengal and Eastern India. Here most of the orchards are very old and they are not managed time to time. As a result much leaves, branches and outgrowths are produced. Which hamper the fruit production sufficiently. As a result the farmers cannot make much profit. Vegetative growth of the species has been realized to be the main hindrance to get better productivity. This vegetative growth can be controlled by pruning and thinning or utilizing various growth regulators.

So, to prevent the vegetative growth in 'Himsagar' mango, paclobutrazol is used. Paclobutrazol, the growth retardants act as inhibitors of mono-oxygenases catalyzing the oxidative steps from ent-kaurene to entkaurenoic acid of biosynthesis path way of GA (Rademacher, 2000). Khader (1991) reported that paclobutrazol reduced the plant height, trunk girth, number of new shoots, 
internodal length and total plant weight in mango cv. Dashehari. Singh et al., (2004) reported the effect of paclobutrazol @ 5 or 10 g.a.i./tree on 25 years old mango cv. Dasheri, reduced shoot and inter node length. The percentage of new shoots, length and diameter of terminal shoots, number of leaves and leaf area were significantly reduced by the soil application of Cultar (Barun and Kumar, 2008).

Paclobutrazol is eco-friendly and nontoxic, can safely be used in crop fields having various influential roles in physiological system of mango plants is well known, but is unknown or little known about its effects on different seasonal fractions.

Hence the present experiment was conducted in mango cv. Himsagar to study the effect of paclobutrazol on different vegetative structure production in different months of the year.

\section{Materials and Methods}

The experiment was conducted at the Central Research Farm of Krishi Vigyan Kendra, Bidhan Chandra Krishi Viswavidyalaya, Gayeshpur, Nadia, West Bengal, India during the years 2015-2016. Soil was sandy loam in nature. The experimental material was 15 years old un-pruned grafted mango plant cv. Himsagar which were established in randomized block design in the experimental field.

The staggered application of paclobutrazol was applied at soil, in the $1^{\text {st }}$ day of first week of month standing from July to February. A ring approximately of $60 \mathrm{~cm}$ radius was dug around the tree and paclobutrazol@ 2.5g.a.i. was dissolved in 5 liters of water and uniformly applied in the ring of plant. Subsequently no irrigation was given in the orchard till flowering. The experiment consisit of nine (including one control) treatments combinations in three replications and forty five plants are located per hector. ( $2^{\text {nd }}$ July) 6 months before flowering application of paclobutrazol @ 2.5g.a.i/ tree the canopy spread $\left(\mathrm{T}_{1}\right),\left(2^{\text {nd }}\right.$ August $) 5$ months before flowering application of paclobutrazol @ 2.5g.a.i/tree the canopy spread $\left(\mathrm{T}_{2}\right),\left(2^{\text {nd }}\right.$ September) 4 months before flowering application of paclobutrazol @ 2.5g.a.i/tree the canopy spread $\left(\mathrm{T}_{3}\right),\left(2^{\text {nd }}\right.$ October $) 3$ months before flowering application of paclobutrazol @ 2.5g.a.i/tree the canopy spread $\left(\mathrm{T}_{4}\right),\left(2^{\text {nd }}\right.$ November) 2 months before flowing application of paclobutrazol @ $2.5 \mathrm{~g} . \mathrm{a} . \mathrm{i} /$ tree the canopy spread $\left(\mathrm{T}_{5}\right),\left(2^{\text {nd }}\right.$ December) 1 month before flowering application of paclobutrazol @ 2.5g.a.i/tree the canopy spread $\left(\mathrm{T}_{6}\right),\left(2^{\text {nd }}\right.$ January) the months of flowering application of paclobutrazol @ 2.5g.a.il/tree the canopy spread $\left(\mathrm{T}_{7}\right),\left(2^{\text {nd }}\right.$ February) 1 month after flowering application of paclobutrazol @ 2.5 g.a.i/tree the canopy spread $\left(\mathrm{T}_{8}\right)$.

\section{Method of observation}

\section{Terminal shoots length}

Terminal shoot length was measured in centimeter with a measuring scale.

\section{Terminal shoots girth}

Terminal shoot diameter was measured in centimeter with a slide calipers and then its girth was calculated by the following way -

Girth $=2 \pi \mathrm{r}$ here, $\mathrm{r}=\frac{D}{2}, \mathrm{D}=$ diameter $\pi=$ constant

\section{Number of newly produced shoots per} Plant

Total numbers of newly formed shoots were counted per plant at different treatment and different months. 


\section{Spatial distribution of newly formed shoots} per plant

After $1^{\text {st }}$ year observed newly formed shoots were formed much more in numbers in primary, secondary and tertiary branches were counted.

\section{Number of leaves per terminal shoots}

Total number of leaves was counted per terminal shoot of a plant at different treatment and different months.

\section{Leaf length}

Leaf length was measured in centimeters with measuring scale from tip to base of leaf.

\section{Leaf width}

Width of leaf was measured in centimeter with measuring scale from middle part of leaf lamina.

\section{Leaf area}

Leaf area was measured by leaf area meter.

\section{Trunk girth}

Trunk perimeter was measured in $\mathrm{cm}$. with the help of measuring tape and then it's crosssectional area of trunk girth, month wise relative growth of cross-sectional area and annual relative growth of the cross-sectional area of the trunk was calculated by the following way -

Cross-sectional area $(A)=\pi r^{2}$ here, $\mathrm{r}=\frac{x}{2 \pi} \quad x=$ value of perimeter,

$\pi=$ constant

Annual relative growth of cross-sectional area $=\frac{\text { value }(A) \text { of } 2 \text { nd year }- \text { value }(A) \text { of 1styear }}{\text { value }(A) \text { of 1styear }} X 100$

\section{Fresh and dry weight}

Terminal shoot with leaves ware collected from plants and each shoot weighted (fresh weight) separately as, leaf, branch bark and wood then put it into the hot air oven at $27^{\circ} \mathrm{C}$ for a month. After the time weight separately (dry weight) and then the moisture percentage and percentage of dry weight distribution was calculated by following way-

$$
\begin{aligned}
& \text { Moisture } \quad \begin{array}{c}
\text { percentage } \\
\text { Fresh weight-Dry weight } \\
\text { Fresh weight }
\end{array} 100
\end{aligned}
$$

Percentage of dry weight distribution $=\frac{\text { Dryweight of part of shoot }}{\text { Total dryweight of shoot }} \times 100$

\section{Results and Discussion}

The vegetative responses of mango plants to the collar application of paclobutrazol were studied in terms of the length of terminal shoots, girth of terminal shoots, number of newly produced shoots/plant, spatial distribution of new shoots, number of leaves per terminal shoot, leaf length, leaf width, leaf area, trunk girth and distribution of dry weight. The state of these vegetative parameters had been measured monthly starting from the month of July. For comparing the effect of the treatments on the growth of the vegetative organs, values for the treatments in the month of December, January and February were statistically analysed as these are the months either of panicles appearance or months that either precedes or follows panicles appearance.

The shoot length (Fig. 1) of the treated plants was significantly shorter than the control plants clearly indicating inhibitory effect of paclobutrazol on the shoot elongation. Among the treated plants, the shortest shoot length was observed in September treated plants in during the month of December $(5.26 \mathrm{~cm})$, 
January $(5.53 \mathrm{~cm})$, and February $(6.74 \mathrm{~cm})$ indicating that in the second year also September application of paclobutrazol was most effective in inhibiting the shoot elongation at and around the time of panicle initiation. The shoot girth (Fig. 2) of all the treated plants was significantly lower than the control plants clearly indicating inhibitory effect of paclobutrazol on the growth of the shoot girth. Shoot girth of November $(1.18 \mathrm{~cm})$, September $(1.20 \mathrm{~cm})$, August $(1.21 \mathrm{~cm})$, October $(1.23 \mathrm{~cm})$ and July $(1.26)$ treated plants was observed to be more or less same and lowest among the treated plants during the month of December; where as that of August $(1.24 \mathrm{~cm})$, September $(1.25 \mathrm{~cm})$, October (1.29), November $(1.29 \mathrm{~cm})$ and $\operatorname{July}(1.29 \mathrm{~cm})$ treated plants was more or less same and lowest during the month of January and that of September $(1.25 \mathrm{~cm})$, August (1.26), October $(1.30 \mathrm{~cm})$ and July $(1.31 \mathrm{~cm})$ treated plants was more or less same and lowest during the month of February indicating that the application of paclobutrazol in the month of July, August, September and October was equally effective in inhibiting the growth of the shoot girth.

In the 'on- year' for the control plants, the number of new shoots (Table 1) in control plants was fewer than the treated plants and this value of the control plants was even fewer than its 'off-year' new shoot frequency. Interestingly the number of new shoots appeared in the treated plants was notably higher than the control plants in the second year during post application period. However if compared with the corresponding values of the first year, only August (77.33) and September (60.00) treated plants produced more number of new shoots in the second year. The total number of new shoots (Table 1) from the branches of different orders in the august (77.33), September (60.00) and October (62.67) treated plants was significantly higher than the control plants. The results clearly indicated the substantial influence of the paclobutrazol on formation of new shoot and the time of its application was crucial in obtaining the positive effect. Appearance of new shoots from the primary branches occurred only in cases of four treatments and the order of frequency was September (23.00)> October (17.67)>August (12.00)>November (1.00) treated plants. Appearance of new shoot from the secondary branches (Plate-3) occurred in all the treatments including control except February treated plants but frequency of new shoots was significantly and spectacularly higher in the plants treated with paclobutrazol between August(47.33) and November (12.67) treated plants. Appearance of new shoot from the terminal branches was highest in July (48.00) treated plants followed by Control (22.67), December (19.33), August (18.00), November (14.00), October (13.33), February (9.33), January (3.33) and September (1.67) treated plants. The results showed that as a consequence of the application of paclobutrazol for consecutive years the frequency of new shoots and their spatial position appeared to have changed greatly (Fig. 3).

In the August, September and October treated plants the most of the new shoots appeared unnaturally from the secondary and primary branches where as in control and July treated plants the new shoots appeared from their natural site of terminal branches. The number of leaves per twig (Fig. 4) of most of the treated plants was significantly lower than that of the control plants clearly indicating the inhibitory effect of paclobutrazol on the number of leaves per twig. Among the treated plants, the lowest number of leaves per twig was observed in September treated plants during the month of December (7.30), January (7.30), and February (7.53) indicating that in the second year also September application of paclobutrazol was most effective in inhibiting the leaf formation. 
Table.1 Number of newly produced shoots in mango plants treated with paclobutrazol on different dates

\begin{tabular}{|c|c|c|c|c|c|c|c|c|c|}
\hline \multirow[b]{2}{*}{ Treatments } & \multicolumn{9}{|c|}{ Number of newly produced shoots per plant in the month of } \\
\hline & $\stackrel{\lambda}{\Xi}$ & $\begin{array}{l}\overrightarrow{w_{0}} \\
\vec{E} \\
\vec{z} \\
\vec{z}\end{array}$ & 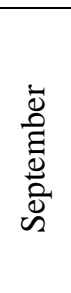 & $\begin{array}{l}\frac{\bar{\nu}}{0} \\
\frac{0}{0} \\
0\end{array}$ & $\begin{array}{l}\bar{D} \\
\text { है } \\
\overrightarrow{0} \\
\overrightarrow{0} \\
z\end{array}$ & 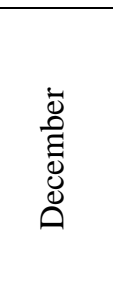 & 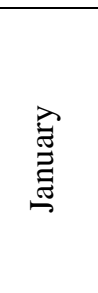 & $\begin{array}{l}\vec{E} \\
\vec{\Xi} \\
\frac{0}{0} \\
\text { I }\end{array}$ & $\begin{array}{c}\text { Total } \\
\text { (Treated*/ } \\
\text { Control since } \\
\text { treatment } \\
\text { date**) }\end{array}$ \\
\hline $\mathrm{T}_{0}$ & 0.00 & 11.33 & 0.00 & 2.00 & 3.67 & 0.00 & 7.00 & 0.00 & 24.00 \\
\hline $\mathrm{T}_{1}$ & 6.00 & 2.00 & 0.00 & 6.67 & 0.00 & 0.00 & 36.33 & 0.00 & $51.00 / 24.00$ \\
\hline $\mathrm{T}_{2}$ & & 21.33 & 1.00 & 18.00 & 0.00 & 5.33 & 0.00 & 31.67 & $77.33 / 24.00$ \\
\hline $\mathrm{T}_{3}$ & & & 2.67 & 36.33 & 0.00 & 21.00 & 0.00 & 0.00 & $60.00 / 12.67$ \\
\hline $\mathrm{T}_{4}$ & & & & 39.33 & 11.67 & 0.00 & 11.67 & 0.00 & $62.67 / 12.67$ \\
\hline $\mathrm{T}_{5}$ & & & & & 8.33 & 0.00 & 4.00 & 15.33 & $27.67 / 10.67$ \\
\hline $\mathrm{T}_{6}$ & & & & & & 0.00 & 16.67 & 5.67 & $22.33 / 7.000$ \\
\hline $\mathrm{T}_{7}$ & & & & & & & 0.00 & 5.67 & $5.67 / 7.000$ \\
\hline $\mathrm{T}_{8}$ & & & & & & & & 9.35 & $9.35 / 0$ \\
\hline SEM ( $( \pm)$ & & & & & & 1.148 & 1.877 & 1.832 & \\
\hline $\mathrm{CD}(\mathrm{P}=0.05)$ & & & & & & 3.537 & 5.693 & 5.491 & \\
\hline
\end{tabular}

$\mathrm{T}_{0}$ (Control), $\mathrm{T}_{1}$ (July application), $\mathrm{T}_{2}$ (August application), $\mathrm{T}_{3}$ (September application), $\mathrm{T}_{4}$ (October application), $\mathrm{T}_{5}$ (November application), $\mathrm{T}_{6}$ (December application), $\mathrm{T}_{7}$ (January application) and $\mathrm{T}_{8}$ (February application)

*The number of new shoot produced during post application period of the concerned treatment. ** The number of new shoot produced during same period in the control.

Fig.1 Terminal shoot length $(\mathrm{cm})$ of mango plants treated with staggered application of paclobutrazol on different dates

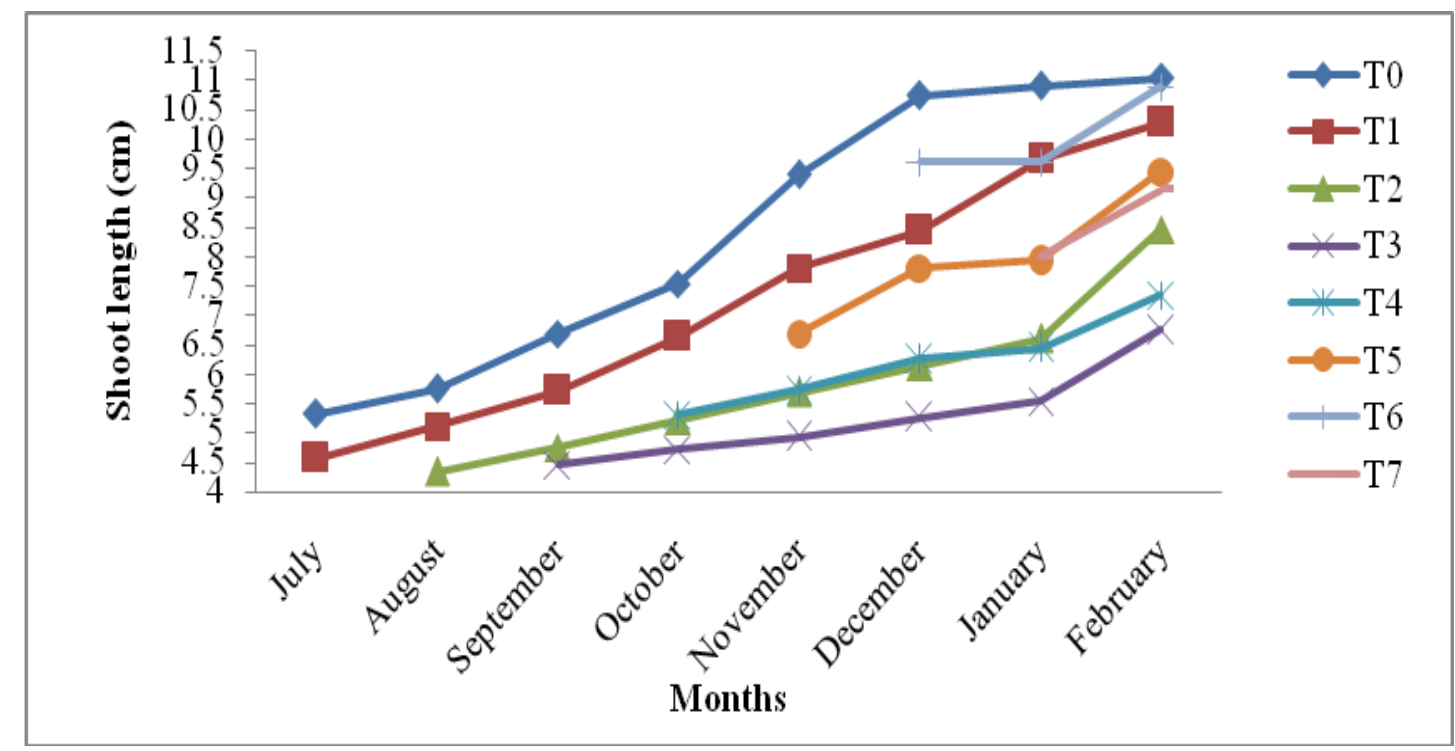


Fig.2 Terminal shoot girth $(\mathrm{cm})$ of mango plants treated with staggered application of paclobutrazol on different dates

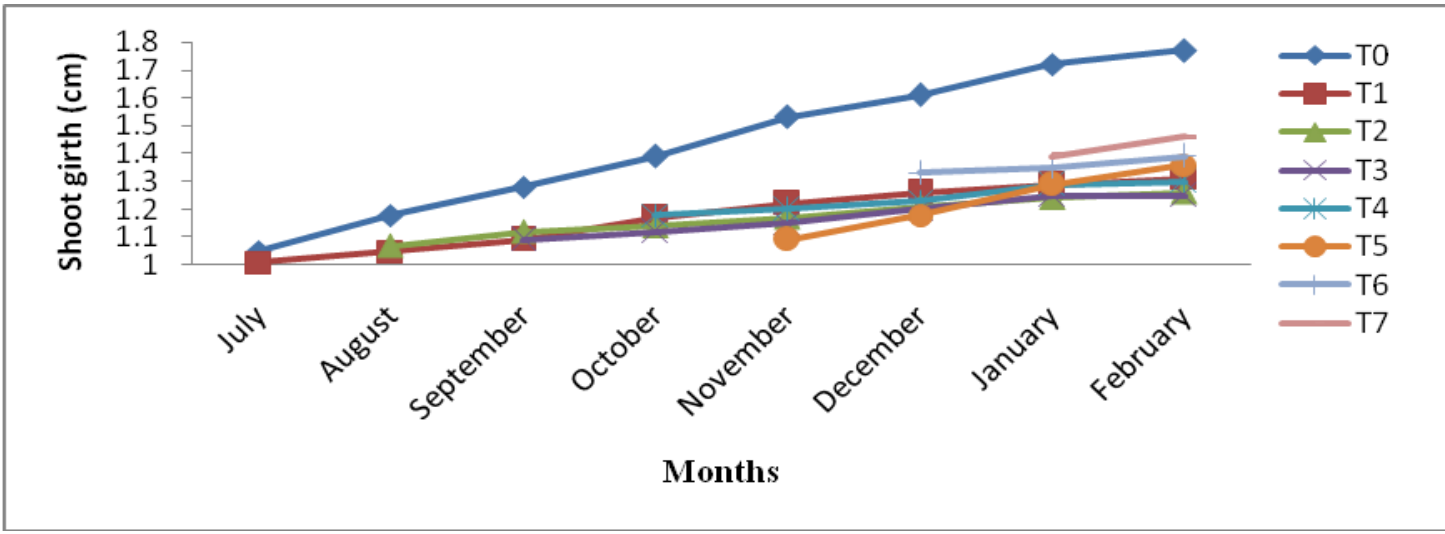

Fig.3 Spatial distribution of newly formed shoots per plant treated with paclobutrazol on different dates

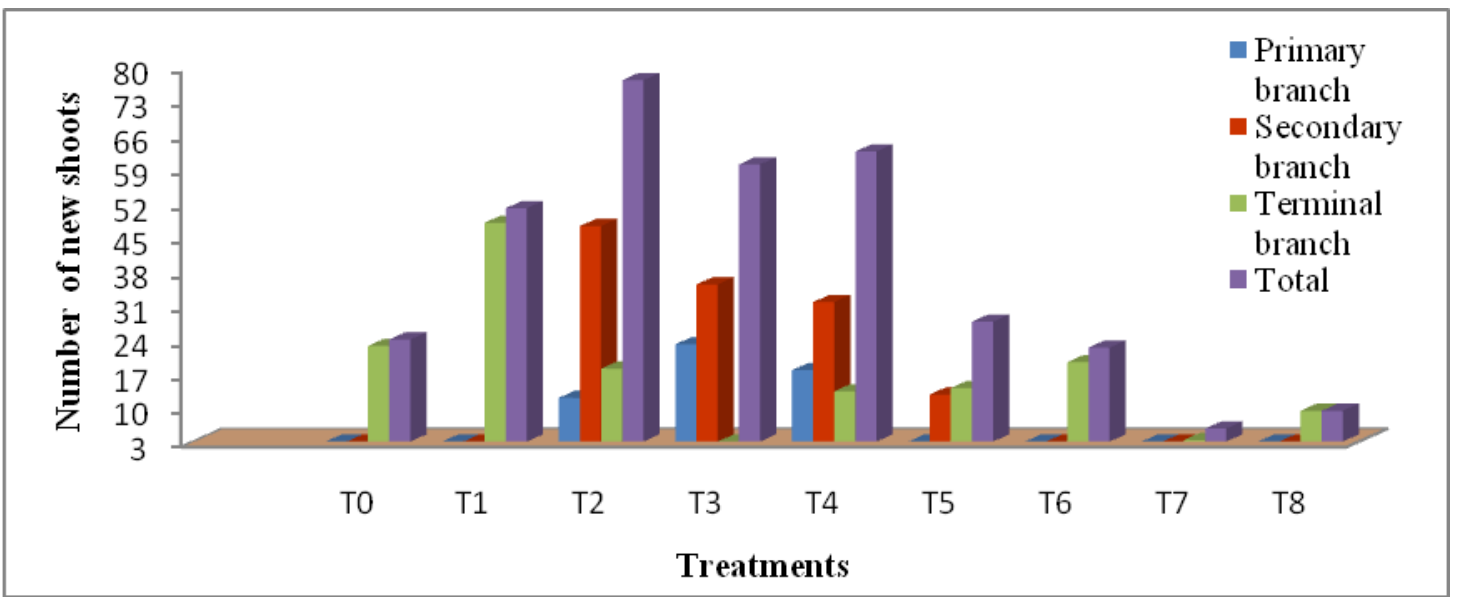

Fig.4 Number of leaves per shoot of the mango plant treated with staggered application of paclobutrazol on different dates

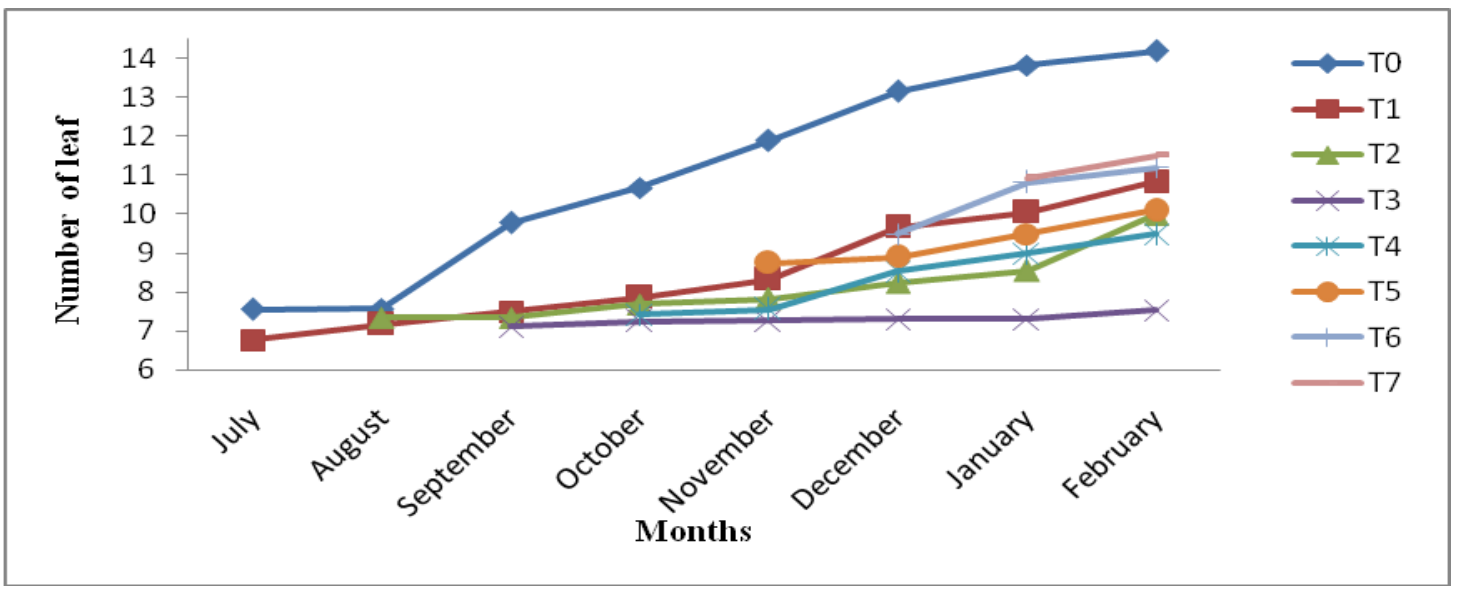


Fig.5 Length $(\mathrm{cm})$ of leaf of the mango plant treated with staggered application of paclobutrazol on different dates

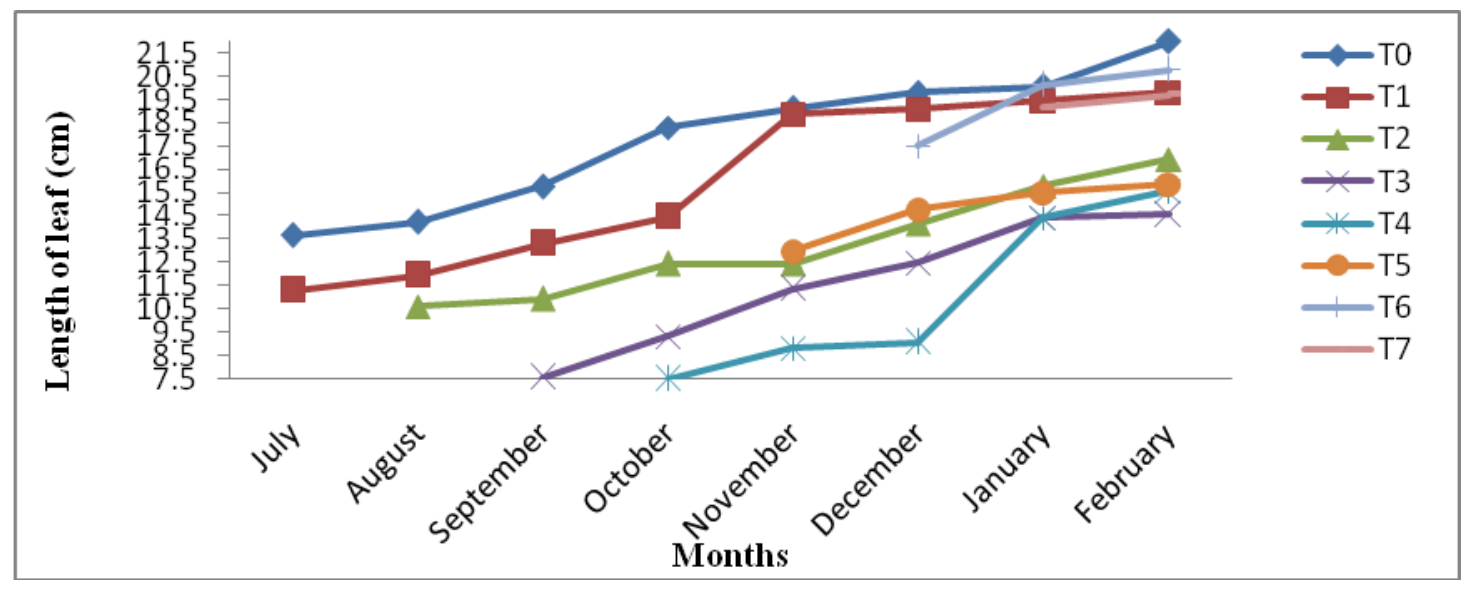

Fig.6 Width $(\mathrm{cm})$ of leaf of the mango plant treated with staggered application of paclobutrazol on different dates

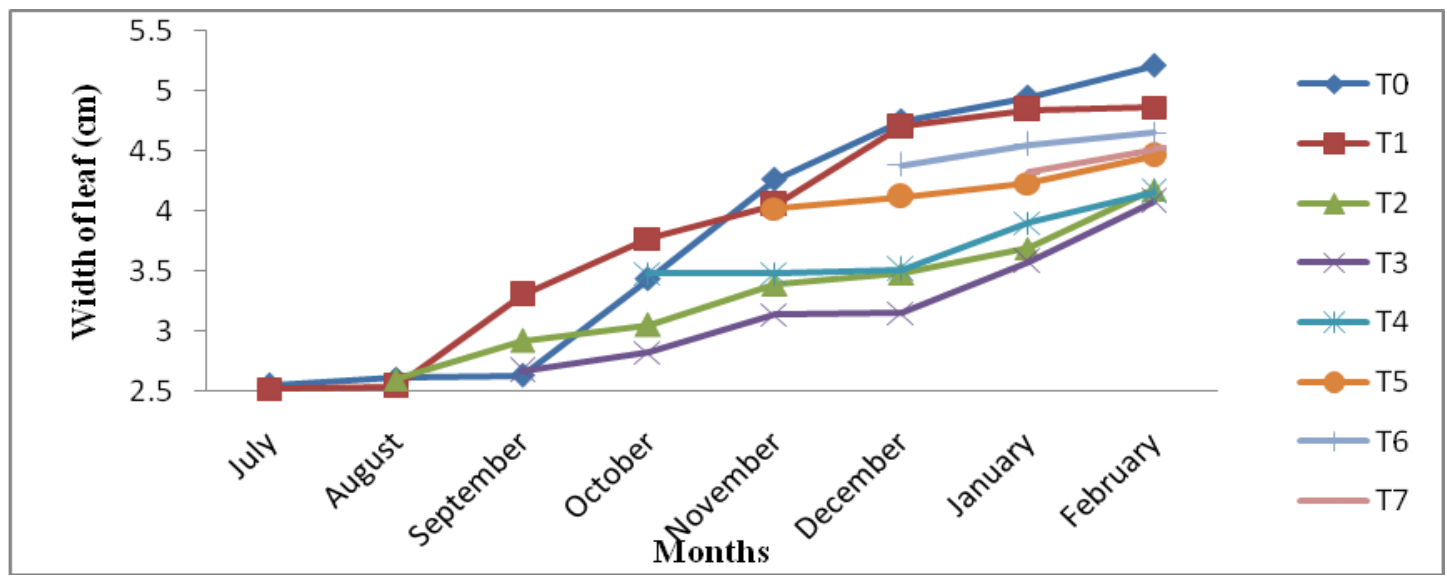

Fig.7 Leaf area $\left(\mathrm{mm}^{2}\right)$ of the mango plant treated with staggered application of paclobutrazol on different dates

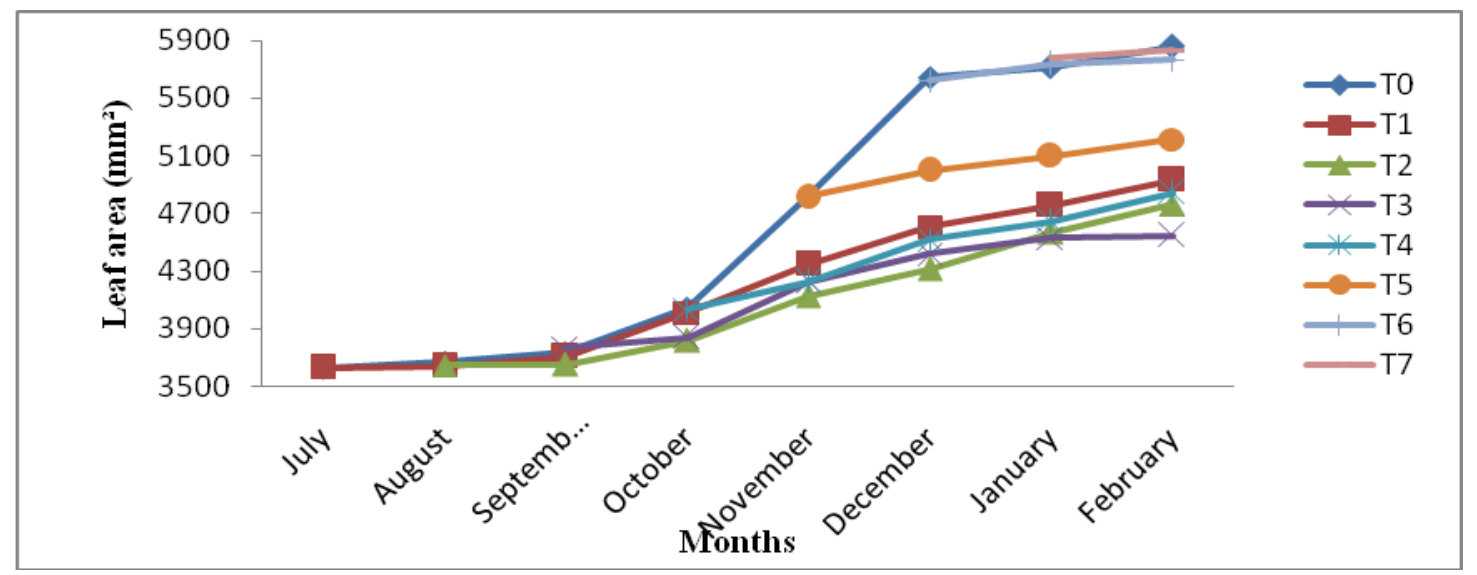


Fig.8 Month wise relative growth of cross-sectional area of trunk of the mango plant treated with staggered application of paclobutrazol on different dates

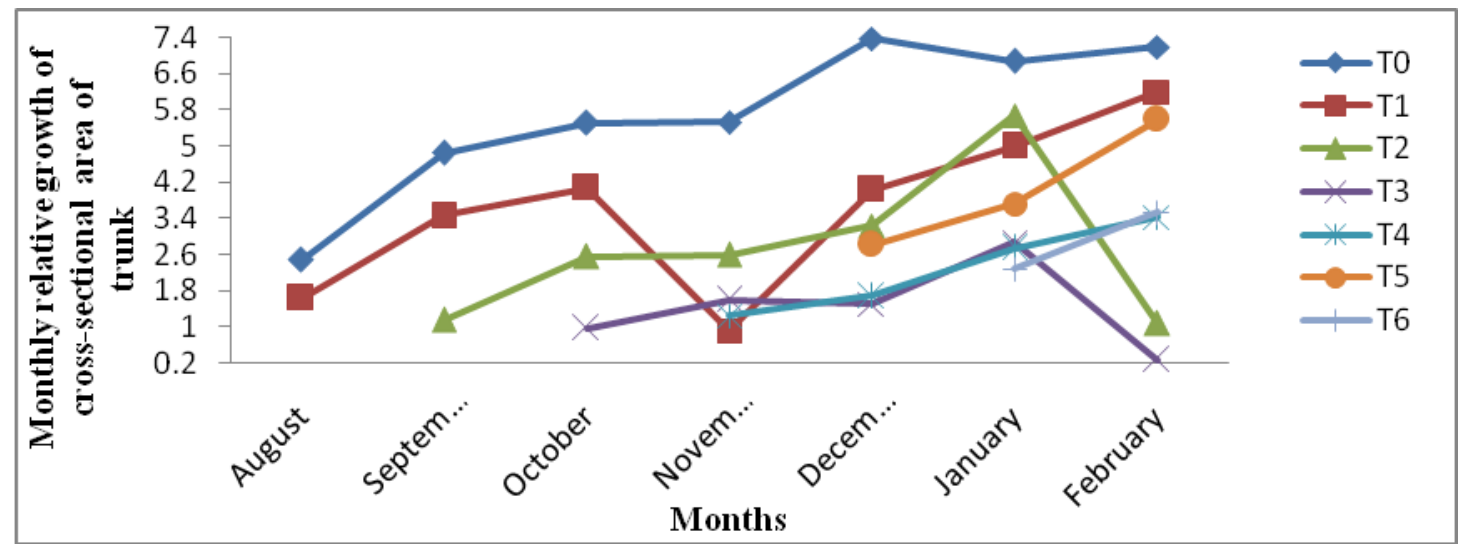

Fig.9 Annual relative growth of the cross-sectional area of the trunk of the mango plant treated with staggered application of paclobutrazol on different dates

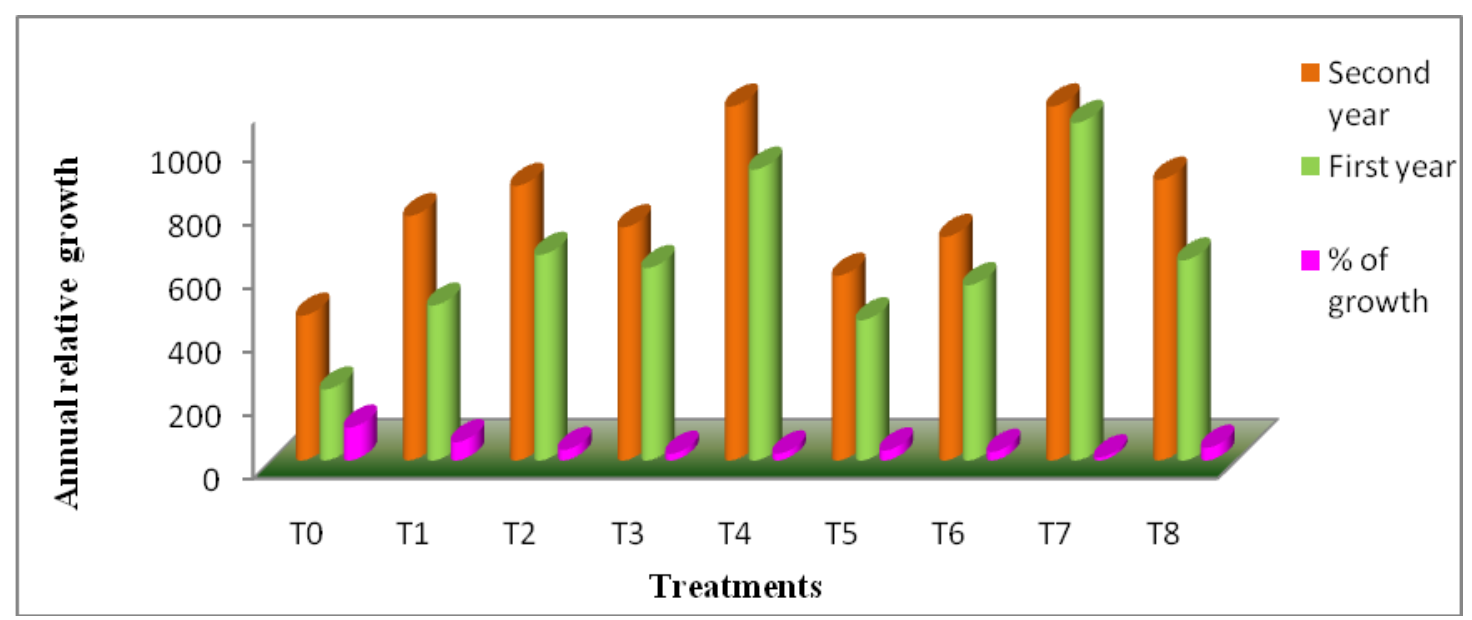

Fig.10 Fresh weight of different part of terminal shoot of the mango plant treated with staggered application of paclobutrazol on different dates

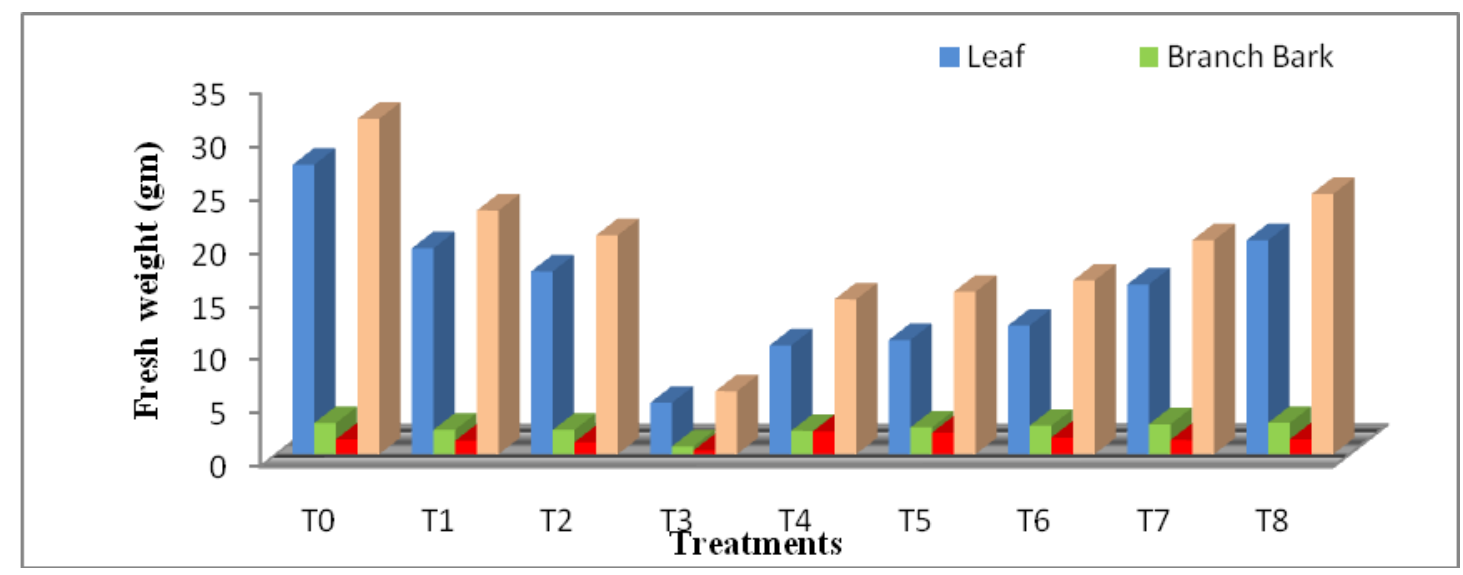


Fig.11 Dry weight of different part of terminal shoot of the mango plant treated with staggered application of paclobutrazol on different dates

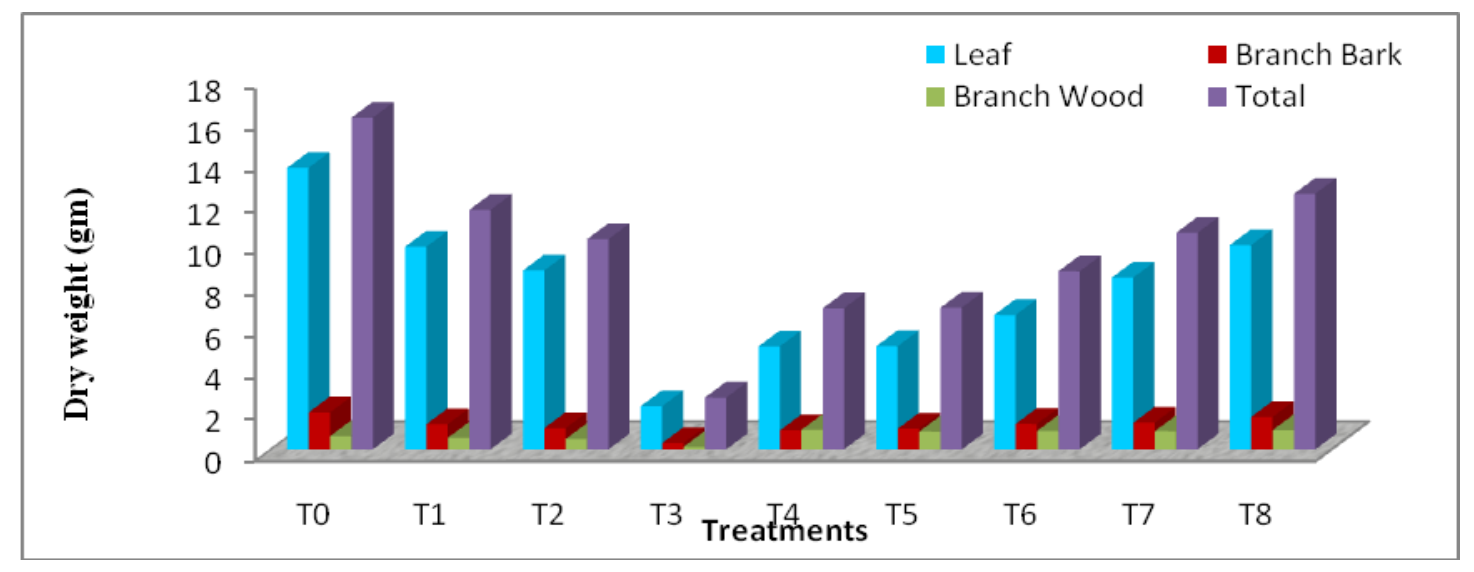

Fig.12 Moisture percentage of different part of terminal shoot of the mango plant treated with staggered application of paclobutrazol on different dates

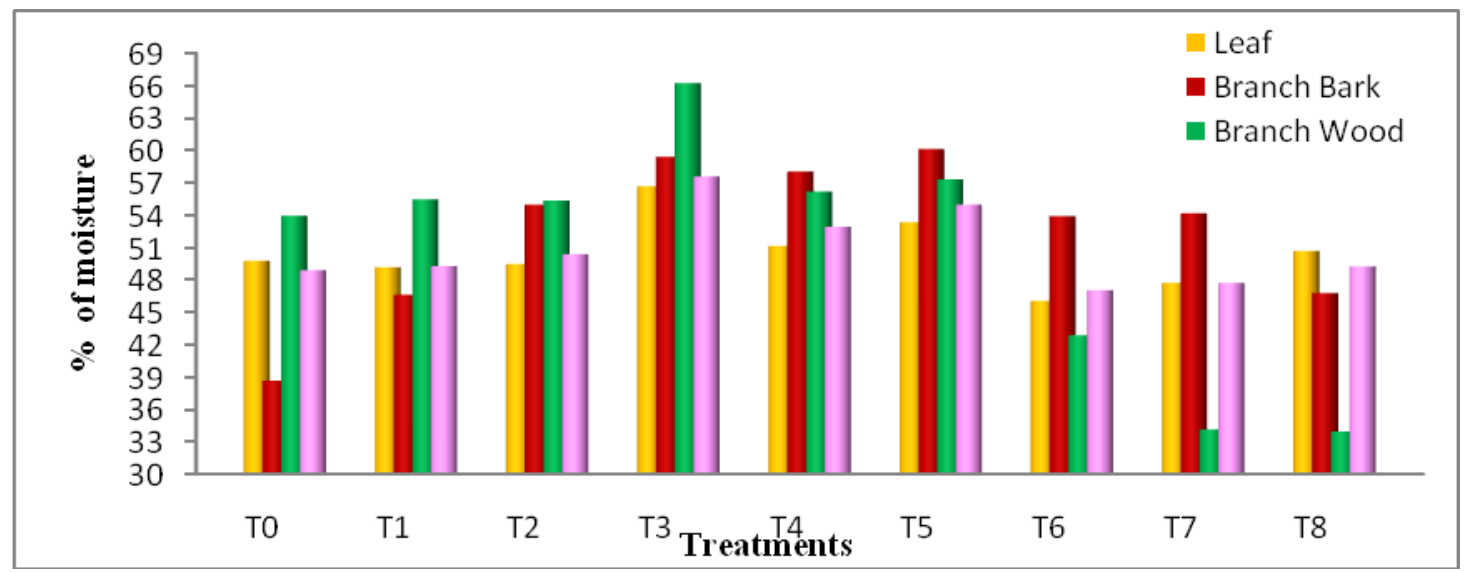

Fig.13 Distribution of Dry weight of the terminal shoots of mango plant treated with staggered application of paclobutrazol on different dates

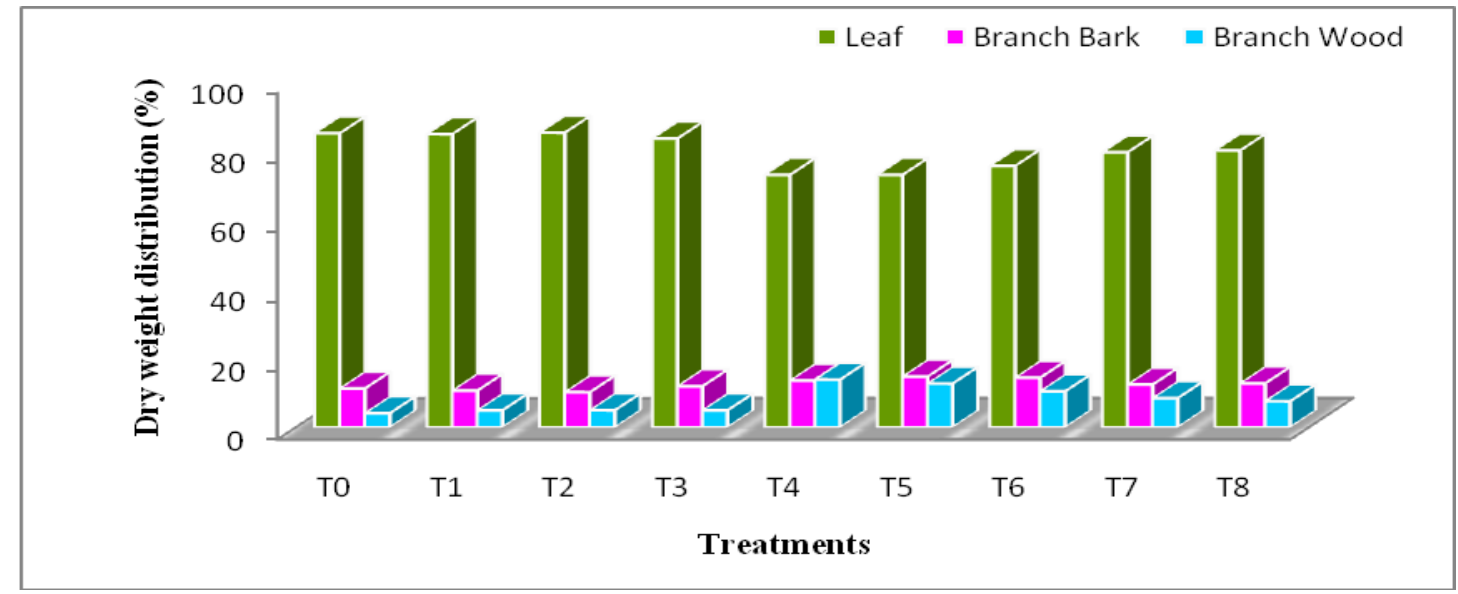


Plate.1 New vegetative shoots from different lower order branch

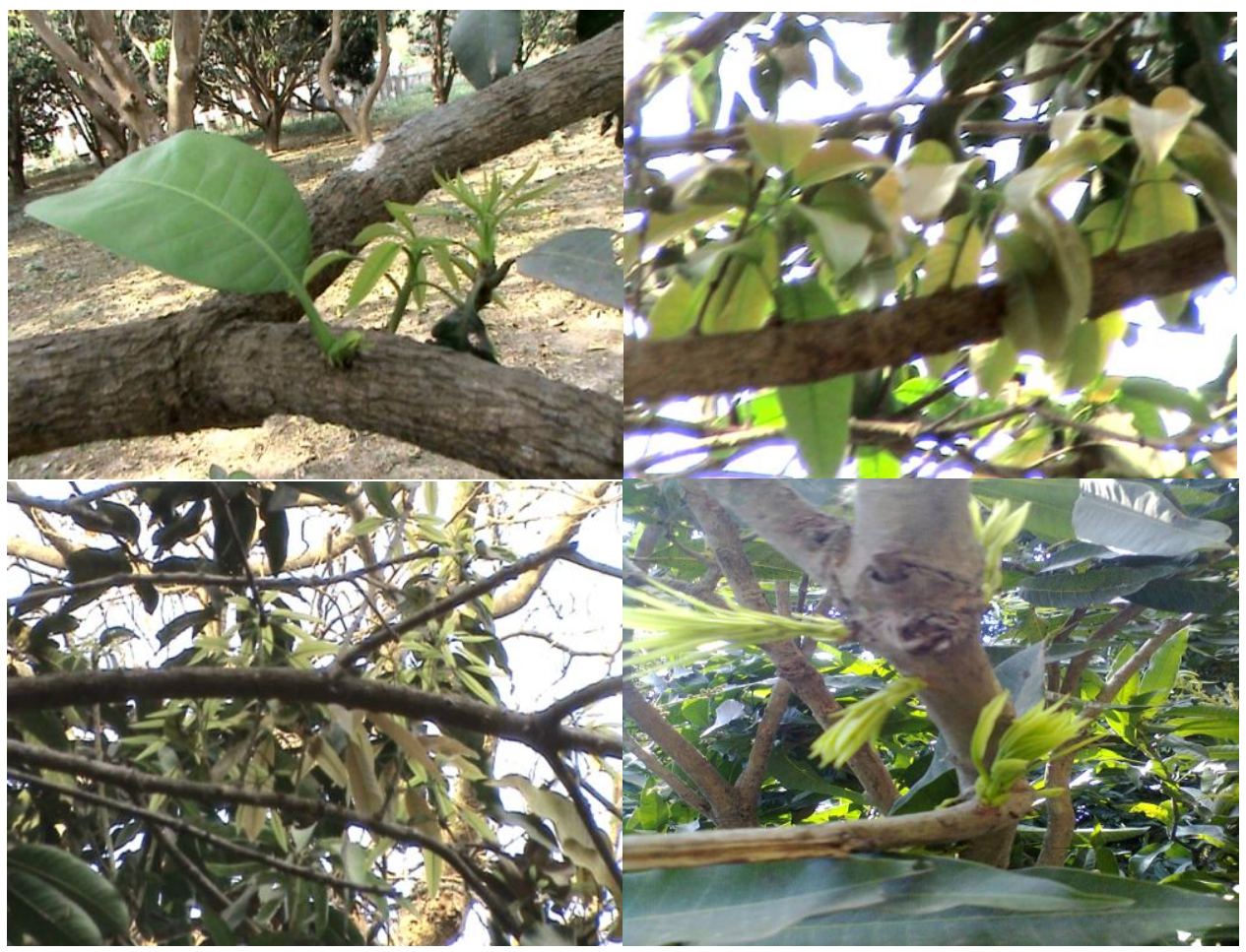

The leaf length (Fig. 5) of the treated plants was significantly shorter than the control plants clearly indicating inhibitory effect of paclobutrazol on the length of leaf and the significantly shorter initial readings of the current applications in the second year clearly showed the residual inhibitory effect of paclobutrazol to the plant of the previous year of application. Among the treated plants, the shorter length of leaf was observed in October treated plants during the month of December $(9.08 \mathrm{~cm})$; in October $(14.43 \mathrm{~cm})$, September $(14.43 \mathrm{~cm})$ treated plants during the month of January and in September $(14.55 \mathrm{~cm})$ treated plants during the month of February indicating that in the second year also September application of paclobutrazol was most effective in inhibiting the leaf length.

The width of leaf (Fig. 6) of the treated plants was significantly shorter than the control plants clearly indicating inhibitory effect of paclobutrazol on the width of leaf and significantly lower initial readings of the current applications in the second year clearly showed the residual inhibitory effect of paclobutrazol to the plant of the previous year of application. Among the treated plants, the shortest width of leaf was observed in September treated plants during the month of December $(3.15 \mathrm{~cm})$, January $(3.58 \mathrm{~cm})$, and February $(4.08 \mathrm{~cm})$ indicating that in the second year also September application of paclobutrazol was most effective in inhibiting the width of leaf.

The leaf area (Fig. 7) of the treated plants was significantly smaller than the control plants clearly indicating inhibitory effect of paclobutrazol on the area of leaf. Among the treated plants, the smallest area of leaf was observed in August (4313.82 $\mathrm{mm}^{2}$ ) and September $\left(4416.86 \mathrm{~mm}^{2}\right)$ treated plants during the month of December; in September $\left(4530.75 \mathrm{~mm}^{2}\right)$, August $\left(4567.33 \mathrm{~mm}^{2}\right)$ and October $\left(4646.13 \mathrm{~mm}^{2}\right)$ treated plants during the month of January and in September $\left(4547.07 \mathrm{~mm}^{2}\right)$ treated plants during the 
month of February indicating that September application of paclobutrazol was most effective in inhibiting the area of leaf.

The month wise relative growth rate (Fig. 8) of the cross sectional area of the trees of the treated plants was comparatively lower than the control plants. Among the treated plants, it was lower in September, August and October treated plants. The annual growth rate (Fig. 9) of the cross sectional area of treated plants also was by far lower than the control plants. Such results indicated that the paclobutrazol has an inhibitory effect on the growth of the cross sectional area of the trunk of mango trees.

The total dry weight (Fig. 10 and 11), leaf dry weight and bark dry weight of the new shoots of all the treated mango plants were significantly lower than those of the control plants. But the wood weight was significantly lower in September (0.12gm) and August $(0.50 \mathrm{gm})$ treated plants and significantly higher in October $(0.94 \mathrm{gm})$, February $(0.93 \mathrm{gm})$, December $(0.89 \mathrm{gm})$, January $(0.88 \mathrm{gm})$ and November $(0.86 \mathrm{gm})$ treated plants in comparison to that of the control $(0.64 \mathrm{gm})$ plants. The September treatment in all such cases was the lowest. Such results strongly indicated the negative effect of paclobutrazol on growth, dry matter accumulation (DMA) and primarily assimilate allocation in new vegetative shoots. Interestingly, paclobutrazol, depending on date of application, caused both negative and positive effect on dry weight accumulation in wood. The percentage of moisture (Fig. 12) of the bark tissues of the all the treated plants were significantly higher than that of the control plants indicating sappy bark tissue of the new shoots as an effect of paclobutrazol which may be due to high sugar content in the bark tissues. The percentage of dry matter accumulation (Fig. 13) in the leaves was lower in the September (83.34\%) and onward treatments and at par with July $(84.63 \%)$ and august $(85.05 \%)$ treated plant when it was compared with that of control $(84.87 \%)$ plants. The percentage of DMA in bark was significantly higher in September and onward treatments and at par with July (10.54\%), august $(10.08 \%)$ and September (11.81\%) treated plant when it was compared with that of control $(11.14 \%)$ plants. The percentage of dry matter accumulation in wood was higher in all the treated plants than that of the control plants. Such results indicated that paclobutrazol caused decrease in dry matter accumulation in leaves, and increase in dry matter accumulation in bark and wood though latter one was more prominent.

\section{Acknowledgements}

The authors hereby acknowledge the improvement brought about in this paper due to the valuable comments of editors and referee.

\section{References}

Barun; Kumar, R.(2008). Bienniality alleviation of mango cv. LANGRA through confluence of cultar, KNO3 and urea. International Journal of Agricultural Sciences, 4(2): 697-703.

Khader, S. E. S. A. (1991) control of tree height, trank girth, shoot growth and total assimilation in young grafted mango trees by paclobutrazol, Indian J. Hort., 48: 112-115.

Rademacher, W. (2000). Growth retardants: Effects on Gibberellin Biosynthesis and Other Metabolic Pathways, Annu. Rev. Plant Physiol. Plant Mol. Biol., 51: 501-31.

Singh, N.P., Malhi, C.S., Dhillion, W-s (2004).Effect of plant bioregulators on the promotion of flowering in mango cv. Dashehari. Jarnal of Research Punjab Agricultural University, 41(3): 
341-344.

Singh, V.K., Achal-Singh., Singh, A. (2003). Effect of paclobutrazol on regularity of bearing in Mango (Mangifera indica L.). Physiology and Molicular -Biology of plants, 9(2): 239-248

Yeshitela, T., Robbertse, P. J., Stassen, P. J.C
(2004). Paclobutrazol suppressed vegetative growth and improved yield as well as fruit quality of tommy Atkins mango (Mangifera indica L.) in Ethiopia. New Zealand Journal of crop and Horticultural science, 32(3): 281293.

\section{How to cite this article:}

Pal, P., S. Mondal and Kundu, S. 2017. Effect of Paclobutrazol on Vegetative Response Production of Mango (Mangifera indica L., var. Himsagar). Int.J.Curr.Microbiol.App.Sci. 6(12): 1264-1275. doi: https://doi.org/10.20546/ijcmas.2017.612.143 